\title{
IN VITRO ANTIOXIDANT AND FREE RADICAL SCAVENGING POTENTIAL OF METHANOLIC EXTRACTS OF UVARIA CHAMAE LEAVES AND ROOTS
}

\author{
NWOKOLO LORRETA NWAKAEGOa, ONYEKWELU KENECHUKWU CHIBUIKEa ${ }^{*}$, ENE MARTIN CHUKWUGEKWU, \\ ADILIEJE CHIOMA MARYLYNa, EZECHUKWU IFUNANYA NGOZIa, EZEH RICHARD CHUKWUNONYEc
}

\begin{abstract}
aDepartment of Medical Biochemistry, College of Medicine, University of Nigeria, Enugu Campus, Enugu State Nigeria, bepartment of Chemical Pathology, University of Nigeria Enugu Campus Medical Centre, Enugu State Nigeria, cDepartment of Medical Biochemistry, ESUT College of Medicine, Parklane, Enugu Nigeria

Email: kenechukwu.onyekwelu@unn.edu.ng
\end{abstract}

Received: 25 Aug 2018 Revised and Accepted: 23 Nov 2018

\section{ABSTRACT}

Objective: This study investigated the in vitro antioxidant and free radical potentials of methanol extracts of Uvaria chamae leaves and roots.

Methods: Fresh Uvaria chamae leaves and roots were air dried, pulverized and extracted using methanol. Phytochemical, total phenolic, flavonoids, antioxidant and tannin contents, DPPH, hydroxyl, and superoxide radical scavenging properties of the extracts were determined using standard methods.

Results: In vitro antioxidant potentials revealed that methanol extract of Uvaria chamae leaves contains vitamin A (4871 \pm 79.21 I. U) and vitamin C $(1.72 \pm 0.02 \%)$ while the root extract contains vitamin A (673.28 $\pm 0.00 \mathrm{I}$. U) and vitamin C $(1.66 \pm 0.01 \%)$. Both extracts had equal contents of vitamin $\mathrm{E}(8.83 \pm 0.04 \mathrm{mg} / 100 \mathrm{~g})$. The leaf extract scavenged 1,1-diphenyl-2-picrylhydrazyl radical (DPPH) in a concentration dependent manner with the correlation coefficient $\left(\mathrm{R}^{2}\right)$ of 0.839 and effective concentration $\left(\mathrm{EC}_{50}\right)$ of $31.19 \mu \mathrm{g} / \mathrm{ml}$, while the root extract scavenged $\mathrm{DPPH}$ with $\mathrm{R}^{2}$ of 0.778 and $\mathrm{EC}_{50}$ of $14.00 \mu \mathrm{g} / \mathrm{ml}$. The leaf and root extracts scavenged superoxide radical and hydroxyl radical with $\mathrm{EC}_{50}$ of $5.93 \mu \mathrm{g} / \mathrm{ml}$ and $719.45 \mu \mathrm{g} / \mathrm{ml}$; $107.89 \mu \mathrm{g} / \mathrm{ml}$ and $912.01 \mu \mathrm{g} / \mathrm{ml}$ respectively compared to the $\mathrm{EC}_{50}$ of ascorbic standard $(30.27 \mu \mathrm{g} / \mathrm{ml})$ and $\mathrm{EC}_{50}$ of vitamin E standard $(106.66 \mu \mathrm{g} / \mathrm{ml})$ respectively. The leaf extract showed significantly higher $(p<0.05)$ anti radical power (ARP) of superoxide (0.17) compared to the root extract $(0.0014)$ and the root extract showed significantly higher $(p<0.05)$ ARP of DPPH $(0.071)$ compared to the leaf extract $(0.032)$.

Conclusion: The leaves and roots of Uvaria chamae are rich in natural antioxidants that can be exploited in the treatment of diseases related to oxidative stress.

Keywords: Uvaria chamae, DPPH, Superoxide radical, Hydroxyl radical

(C) 2019 The Authors. Published by Innovare Academic Sciences Pvt Ltd. This is an open access article under the CC BY license (http://creativecommons.org/licenses/by/4.0/] DOI: http://dx.doi.org/10.22159/ijpps.2019v11i1.29330

\section{INTRODUCTION}

There are several types of antioxidants; natural antioxidants, which are obtained entirely from natural sources and the synthetic antioxidants which are created from chemical processes. Natural antioxidants from plant origin could provide alternatives to synthetic antioxidants. Antioxidants are nature's way of protecting the body and cells from damaging free radicals [1].

Reactive oxygen species (ROS) are highly reactive molecules possessing one or more unpaired electrons generated in living systems in the presence of molecular oxygen.

Mitochondria are the major site of free radical/ROS production in the body through oxidative phosphorylation resulting in the formation of ROS as a by-product of electron transfer reactions. Other endogenous sources of cellular ROS includes the phagocytic cells such as neutrophils, eosinophils and macrophages which generate ROS during the oxidative burst; the peroxisomes which produces hydrogen peroxide under physiological conditions and the cytochrome P450 enzymes which by oxidizing unsaturated fatty acids reduces molecular oxygen to superoxide anion radical and hydrogen peroxide [2-4].

The overproduction of ROS in biological systems leads to an imbalance between the formation of ROS and the antioxidant defence mechanisms, resulting in chemical modifications of cellular DNA, proteins or lipids, which lead to oxidative stress [5-7].

Oxidative stress is implicated in most human diseases. For instance, oxidatively damaged cell membranes lose their functional integrity that could lead to disease states while oxidatively damaged glucose and protein molecules form glycated proteins that can lead to cataracts and other diseases.
Natural antioxidants work by donating an electron to a molecule that has been compromised by oxidation, bringing it back into a state of proper function and having been used up in this way, the antioxidant molecule is either re-charged by accepting an electron from another type of antioxidant or it is re-cycled. Contrary to the natural antioxidants, the synthetic antioxidants cannot be recycled and re-used by the organism once they have donated their electron and as a result of this, they tend to turn into harmful metabolic by products that increase, rather than decreasing the total load of oxidative stress on the organism. Since efficient antioxidant protective mechanisms are crucial to inhibit oxidative stress, there has been an intensified search for natural antioxidant that could serve as a replacement for synthetic antioxidants which have some adverse effects in the body. As a result of this, we initiated this study to investigate the in vitro antioxidant and free radical potentials of methanol extracts of Uvaria chamae leaves and roots.

\section{MATERIALS AND METHODS}

\section{Plant materials (Uvaria chamae)}

The Uvaria chamae leaves and roots were sourced locally from Awlaw town in Oji River Local Government Area of Enugu State. These materials were identified and authenticated by Mr A. Ozioko of bioresources diversity and conservative programme (BDCP) unit, University of Nigeria. A specimen was deposited in the herbarium for future reference with a voucher number of UNH $471 \mathrm{~b}$.

\section{Chemicals/Reagents}

All chemicals used in this study were of analytical grade and products of Sigma Aldrich, (USA), British drug house (BDH) (England), Burgoyne (India), Harkin and Williams, (England), 
Qualikems, (India), Fluka (Germany), May and Baker, (England), LOBA chemie, (India) and J. T Baker (USA).

\section{Extraction}

Large quantity of Uvaria chamae leaves and roots were cut into small pieces and ground into fine powder using a dry grinder. The grounded samples were sieved to get uniform particle size, then kept in an air-tight container and stored for extraction. Methanol extraction was done according to the method of Mahanta and Murkherjee [8] with little modification. The extraction process was carried out by soaking about $200 \mathrm{~g}$ of dried powder in $1000 \mathrm{ml}$ of 80 $\%$ methanol for $24 \mathrm{~h}$. Crude extract was obtained by first filtering through a muslin cloth and further clarified by filtration through filter paper (Whatman No.1). The extracts were concentrated using evaporator set at $50{ }^{\circ} \mathrm{C}$ to get rid of methanol completely. The extracts were kept in the refrigerator for further analysis.

\section{In vitro antioxidant assay}

\section{Phytochemical analysis}

The dried ground leaves and roots were subjected to preliminary phytochemical analysis for flavonoids, tannins, carbohydrates/ glycosides, saponins, resins and alkaloids using standard method as described by Ioan [9].

\section{Determination of total phenolic contents}

Total phenolics were determined using Folin-Ciocalteau reagent (FCR) as described by Velioglu et al. [10], with slight modifications. A $100 \mu \mathrm{l}$ of the extracts dissolved in methanol $(1 \mathrm{mg} / \mathrm{ml})$ was mixed with $750 \mu$ of Folin-Ciocalteu reagent (diluted 10 -fold in $\mathrm{dH}_{2} \mathrm{O}$ ) and allowed to stand at $22{ }^{\circ} \mathrm{C}$ for $5 \mathrm{~min} ; 750 \mu \mathrm{l}$ of $\mathrm{Na}_{2} \mathrm{CO}_{3}(60 \mathrm{~g} / \mathrm{l})$ solution was then added to the mixture. After $90 \mathrm{~min}$, the absorbance was measured at $725 \mathrm{~nm}$. The phenolic content was evaluated from a gallic acid standard curve.

\section{Determination of tannin contents}

Tannin content in each sample was determined using insoluble polyvinyl-polypirrolidone (PVPP), which binds tannins as described by Makkar et al. [11]. A known volume, $1 \mathrm{ml}$ of extract was dissolved in methanol $(1 \mathrm{mg} / \mathrm{ml})$, in which the total phenolics were determined, mixed with $100 \mathrm{mg}$ PVPP, vortexed, left for $15 \mathrm{~min}$ at 4 ${ }^{\circ} \mathrm{C}$ and then centrifuged for $10 \mathrm{~min}$ at $3000 \mathrm{rpm}$. In the clear supernatant, the non-tannin phenolics were determined the same way as the total phenolics. Tannin content was calculated as a difference between total and non-tannin phenolic content.

\section{Determination of flavonoids}

The flavonoid content was determined according to the method described by Kumaran and Karunakaran [12] with slight modifications. A $100 \mu \mathrm{l}$ of plant extracts in methanol $(10 \mathrm{mg} / \mathrm{ml})$ was mixed with $100 \mu \mathrm{l}$ of $20 \%$ aluminium trichloride in methanol and a drop of acetic acid and then diluted with methanol to $5 \mathrm{ml}$. The absorption at $415 \mathrm{~nm}$ was read after $40 \mathrm{~min}$. Blank samples were prepared from $100 \mu \mathrm{l}$ of $20 \%$ aluminium trichloride in methanol and a drop of acetic acid and then diluted to $5 \mathrm{ml}$ with methanol. The absorption of standard quercetin solution $(0.5 \mathrm{mg} / \mathrm{ml})$ in methanol was measured under the same conditions, and the amount of flavonoids in plant extracts in quercetin equivalents (QE) was calculated. Antioxidant vitamins $\mathrm{A}, \mathrm{C}$ and $\mathrm{E}$ were determined using the method of Pearson [13] as described below:

\section{Determination of vitamin A concentration}

One gram $(1 \mathrm{~g})$ of the extract was weighed and macerated with 20 $\mathrm{ml}$ of petroleum ether. The filtrate was collected and evaporated to dryness followed by the addition of $0.2 \mathrm{ml}$ of chloroform acetic anhydride. Two milliliter ( $2 \mathrm{ml}$ ) of trichloroacetic acid (TCA) was added. The absorbance was read at $620 \mathrm{~nm}$ and the amount of vitamin A (IU) calculated.

\section{Determination of vitamin $C$ concentration}

One gram $(1 \mathrm{~g})$ of the extract was weighed and macerated with 10 $\mathrm{ml}$ of $0.4 \mathrm{~g}$ of oxalic acid and filtered. One milliliter $(1 \mathrm{ml})$ of the filtrate was pipetted followed by the addition of $9 \mathrm{ml}$ of indolphenols' reagent. The absorbance was read at $520 \mathrm{~nm}$, and the amount of vitamin C (\%) in the extract was calculated.

\section{Determination of vitamin $\mathrm{E}$ concentration}

One gram $(1 \mathrm{~g})$ of the extract was weighed, macerated with $20 \mathrm{ml}$ of ethanol and filtered. To $1 \mathrm{ml}$ was added $2 \mathrm{ml}$ of $0.2 \%$ ferric chloride in ethanol and $0.5 \% \alpha, \alpha$ or 2,2 dipyridyl and the volume made up to $5 \mathrm{ml}$ with distilled water. The absorbance of the solution was then read at $520 \mathrm{~nm}$ and the amount of vitamin $\mathrm{E}(\mathrm{mg} / 100 \mathrm{~g})$ was calculated.

\section{DPPH radical scavenging assay}

Scavenging activity of the extracts on DPPH free radicals was determined according to the method described by Gyamfi et al. [14] with slight modifications. A $2.0 \mathrm{ml}$ solution of the leaf and root extracts at different concentrations diluted two-fold in methanol was mixed with $1.0 \mathrm{ml}$ of $0.3 \mathrm{mmol}$ DPPH in methanol. The mixture was shaken vigorously and allowed to stand at room temperature in the dark for $25 \mathrm{~min}$. This was repeated for root extract. Blank solutions were prepared with each test sample solution $(2.0 \mathrm{ml})$ and $1.0 \mathrm{ml}$ of methanol while the negative control was $1.0 \mathrm{ml}$ of $0.3 \mathrm{mmol}$ DPPH solution plus $2.0 \mathrm{ml}$ of methanol. Lascorbic acid was used as positive control. Thereafter, the absorbance of the assay mixture was measured at $518 \mathrm{~nm}$ against each blank with a UV-visible spectrophotometer. DPPH radical scavenging activity was calculated using the equation:

$$
\% \text { Inhibition }=100 \% \times\left(\frac{\mathrm{A}_{0}-\mathrm{A}_{\mathrm{s}}}{\mathrm{A}_{0}}\right)
$$

Where $A_{0}$ is the absorbance of the control, and $A_{\mathrm{s}}$ is the absorbance of the tested sample.

\section{Hydroxyl radical $(\cdot \mathrm{OH})$ scavenging assay}

Hydroxyl radical scavenging assay is based on quantification of the degradation product of 2-deoxyribose by condensation with TBA was carried out as described by Elizabeth and Rao [15] with a slight modification. Hydroxyl radical was generated by the Fe3+-ascorbateEDTA- $\mathrm{H}_{2} \mathrm{O}_{2}$ system. The reaction mixture contained, in a final volume of $1 \mathrm{ml}$, 2-deoxy-2-ribose (2.8 mmol); $\mathrm{KH}_{2} \mathrm{PO}_{4}-\mathrm{KOH}$ buffer $(20 \mathrm{mmol}, \mathrm{pH}$ 7.4); $\mathrm{FeCl}_{3}(100 \mu \mathrm{M})$; EDTA $(100 \mu \mathrm{M}) ; \mathrm{H}_{2} \mathrm{O}_{2}(1.0 \mathrm{mmol})$; ascorbic acid $(100 \mu \mathrm{M})$ and various concentrations of the test sample or reference compound. The mixture was incubated for an hour at $37^{\circ} \mathrm{C}$ after which, 0.5 $\mathrm{ml}$ of the reaction mixture was added to $1 \mathrm{ml} 2.8 \%$ TCA, then $1 \mathrm{ml} 1 \%$ aqueous TBA was added, and the mixture was incubated again at $90^{\circ} \mathrm{C}$ for $15 \mathrm{~min}$ to develop the color. After cooling, the absorbance was measured at $532 \mathrm{~nm}$ against an appropriate blank solution. Vitamin C, a classical $\mathrm{OH}$ scavenger was used as a positive control. Percentage inhibition was evaluated by comparing the test and blank solutions.

\section{Superoxide radical $\left(\mathrm{O}_{2} \cdot\right)$ scavenging assay}

Superoxide radical activity was measured by the reduction of nitro blue tetrazolium (NBT) according to the method described by Fontana [16]. The non-enzymatic phenazine methosulfate-nicotinamide adenine dinucleotide (PMS/NADH) system generates superoxide radicals, which reduce NBT to a purple formazan. The $1 \mathrm{ml}$ reaction mixture contained phosphate buffer $(20 \mathrm{mmol}, \mathrm{pH} 7.4)$, NADH $(73$ $\mu \mathrm{M})$, NBT $(50 \mu \mathrm{M})$, PMS $(15 \mu \mathrm{M})$ and various concentrations of the sample solution. After incubation for $5 \mathrm{~min}$ at ambient temperature, the absorbance at $562 \mathrm{~nm}$ was measured against an appropriate blank to determine the quantity of formazan generated.

\section{Scavenging properties of extracts on nitric oxide radical (NO)}

Nitric oxide radical (NO) generated from sodium nitroprusside (SNP) was measured according to the method of Marcocci et al. [17]. Briefly, the reaction mixture $(5.0 \mathrm{ml})$ containing SNP (5 mmol) in phosphate buffered saline ( $\mathrm{pH} \mathrm{7.3),} \mathrm{with} \mathrm{or} \mathrm{without} \mathrm{the}$ plant extracts at different concentrations, were incubated at 25 ${ }^{\circ} \mathrm{C}$ for $180 \mathrm{~min}$ in front of a visible polychromatic light source ( $25 \mathrm{~W}$ tungsten lamp). The NO- radical thus generated interacted with oxygen to produce the nitrite ion $\left(\mathrm{NO}_{2}^{-}\right)$which was assayed at 30 -minute intervals by mixing $1.0 \mathrm{ml}$ of incubation mixture with an equal amount of Griess reagent $(1 \%$ sulphanilamide in 5 $\%$ phosphoric acid and $0.1 \%$ naphthylethylenediamine dihydrochloride). The absorbance of the chromophore (purple 
azo dye) formed during the diazotization of nitrite ions with sulphanilamide and subsequent coupling with naphthylethylenediamine dihydrochloride was measured at $546 \mathrm{~nm}$. The nitrite generated in the presence or absence of the plant extract was estimated using a standard curve based on sodium nitrite solutions of known concentrations. Each experiment was carried out at least three times and the data presented as an average of three independent determinations.

\section{Statistical analysis}

Data were reported as means $\pm S$. D, where appropriate. One-way analysis of variance (ANOVA) and correlation analysis was used to analyze the experimental data. Differences were considered significant when $\mathrm{p}<0.05$ and $\mathrm{p}<0.01$.

\section{RESULTS}

The qualitative phytochemical composition of Uvaria chamae leaves and roots showed that proteins, carbohydrates, and tannins were present in higher amount in the leaves while in roots, they were moderately present except tannin that was in trace amount. Saponin was present in higher amount in both the leaf and root. Flavonoids and steroid were present in trace amount in the leaf while in the root, flavonoids were not detected and steroids were moderately present (table 1).

Table 1: Qualitative phytochemical composition of Uvaria chamae leaves and roots

\begin{tabular}{|c|c|c|}
\hline Phytochemicals & Bioavailability (Leaves) & Bioavailability (Root) \\
\hline Protein & +++ & ++ \\
\hline Flavonoids & + & ND \\
\hline Glycosides & ++ & ++ \\
\hline Saponin & +++ & +++ \\
\hline Alkaloid & ++ & + \\
\hline Carbohydrates & +++ & ++ \\
\hline Tannins & +++ & + \\
\hline Steroids & + & ++ \\
\hline
\end{tabular}

Key: +Present in trace amount; ++Present in moderate amount; +++Present in high amount; NDNot detected

The result of quantitative analysis of Uvaria chamae showed that the leaf extract had higher contents of flavonoids and tannins when compared to that of the root extract while the root extract showed higher contents of total phenolic content when compared to that of the leaf extract (table 2).

Table 2: Quantitative phytochemical composition of methanol extracts of Uvaria charmae

\begin{tabular}{lll}
\hline & Leaves & Roots \\
\hline Total Phenolic content & $0.61 \pm 0.16 \mathrm{GAE}$ & $0.69 \pm 0.21 \mathrm{GAE}$ \\
Tannins & $0.44 \pm 0.15 \mathrm{GAE}$ & $0.32 \pm 0.20 \mathrm{GAE}$ \\
Flavonoids & $0.004 \pm 0.0001 \mathrm{mg} \mathrm{QE}$ & $0.0013 \pm 0.0003 \mathrm{mgQE}$ \\
\hline
\end{tabular}

Values are obtained as mean \pm SD. Each value is the mean of three (03) essays $(n=3)$

The antioxidant vitamins concentration of methanol extracts of Uvaria chamae leaves and roots showed that the leaf extract had the highest vitamin A concentration $(4871 \pm 79.21 \mathrm{I}$. U) compared to the root extract $(673.28 \pm 0.00 \mathrm{I}$. $U$ ) While that of the water-soluble vitamin $\mathrm{C}$ concentration slightly varied with the values of $1.72 \pm 0.02 \%$ for the leaf extract and $1.66 \pm 0.01 \%$ for the root extract. Vitamin E concentrations were the same in both extracts with the values of $8.83 \pm 0.04 \mathrm{mg} / 100 \mathrm{~g}$ each.

Table 3: Antioxidant vitamin contents of methanol extracts of Uvaria chamae leaves and roots

\begin{tabular}{lll}
\hline Parameter & Values mean \pm standard deviation (SD) & \\
\hline & Leaf extract & Root extract \\
Vitamin A & $4871 \pm 79.21 \mathrm{IU}$ & $673.28 \pm 0.00 \mathrm{IU}$ \\
Vitamin C & $1.72 \pm 0.02 \%$ & $1.66 \pm 0.01 \%$ \\
Vitamin E & $8.83 \pm 0.04 \mathrm{mg} / 100 \mathrm{~g}$ & $8.83 \pm 0.04 \mathrm{mg} / 100 \mathrm{~g}$ \\
\hline
\end{tabular}

Values are obtained as mean \pm SD. Each value is the mean of three $(03)$ essays $(n=3)$

The scavenging effect of methanol extracts of Uvaria chamae leaves and roots on DPPH radical revealed that the leaf and root extracts scavenged DPPH radical in concentration-dependent manner with the highest percentage inhibition of $70.69 \pm 13.29$ and $76.13 \pm 8.80$ respectively at the concentration of $125 \mu \mathrm{g} / \mathrm{ml}$. The effective concentration $\left(\mathrm{EC}_{50}\right)$ at $50 \%$ inhibition is $31.19 \mu \mathrm{g} / \mathrm{ml}$ for the leaf extract and $14.00 \mu \mathrm{g} / \mathrm{ml}$ for the root extract compared to that of vitamin C (ascorbic acid) standard with $\mathrm{EC}_{50}$ of $25.29 \mu \mathrm{g} / \mathrm{ml}$. Comparison of both leaf and root extracts against percentage inhibition showed a statistically significant positive correlation $(\mathrm{P}<0.05)$ with a correlation coefficient $\left(\mathrm{R}^{2}\right)$ of 0.839 and 0.778 respectively (table 4 ).

Table 4: Scavenging effect of methanol extracts (expressed in $\mu \mathrm{g} / \mathrm{ml}$ ) of Uvaria chamae leaves and roots on DPPH radical

\begin{tabular}{lll}
\hline Concentration $(\boldsymbol{\mu g} / \mathbf{m l})$ & \multicolumn{2}{l}{ Percentage Inhibition $(\%)^{\mathbf{n}}$ mean \pm standard deviation (SD) } \\
\cline { 2 - 3 } & Leaf extract & Root extract vitamin C (standard) \\
\hline 125 & $70.69 \pm 13.29$ & $76.13 \pm 8.8096 .83 \pm 0.02$ \\
62.5 & $62.39 \pm 13.82$ & $68.76 \pm 13.3595 .32 \pm 0.14$ \\
31.25 & $51.28 \pm 9.54$ & $65.30 \pm 13.3367 .48 \pm 5.14$ \\
15.625 & $41.28 \pm 8.64$ & $55.79 \pm 6.7734 .86 \pm 0.34$ \\
7.8125 & $27.49 \pm 10.31$ & $37.73 \pm 3.2718 .20 \pm 0.99$ \\
3.90625 & $9.69 \pm 3.34$ & $23.75 \pm 3.049 .02 \pm 1.79$ \\
1.95325 & $2.71 \pm 0.73$ & $11.78 \pm 7.604 .88 \pm 1.02$ \\
\hline
\end{tabular}

Values are obtained as mean $\pm \mathrm{SD}$. Each value is the mean of three (03) essays ( $\mathrm{n}=3), \mathrm{EC}_{50}$ for leaf extract $=31.19 \mu \mathrm{g} / \mathrm{ml}, \mathrm{EC} 50$ for root extract=14.00 $\mu \mathrm{g} / \mathrm{ml}, \mathrm{EC}_{50}$ for vitamin C (ascorbic acid) standard $=25.29 \mu \mathrm{g} / \mathrm{ml}$. 
The scavenging effects of methanol extracts of Uvaria chamae leaves and roots on superoxide radical revealed an $\mathrm{EC}_{50}$ of $5.93 \mu \mathrm{g} / \mathrm{ml}$ and $719.45 \mu \mathrm{g} / \mathrm{ml}$ for the leaf and root extracts respectively compared to that of vitamin C (ascorbic acid) standard with an $\mathrm{EC}_{50}$ of $30.27 \mu \mathrm{g} / \mathrm{ml}$. Comparison of the concentration of leaf extract against its percentage inhibition showed a positive correlation that was statistically not significant $(\mathrm{P}>0.05)$ with a correlation coefficient $\left(\mathrm{R}^{2}\right)$ of 0.139 while the comparison of the root extract concentration against its percentage inhibition showed a statistically negatively significant correlation $(\mathrm{P}<0.01)$ with a correlation coefficient of -0.855 .

Table 5: Scavenging effect of methanol extracts (expressed in $\mu \mathrm{g} / \mathrm{ml}$ ) of Uvaria chamae leaves and roots on superoxide radical

\begin{tabular}{|c|c|c|}
\hline \multirow[t]{2}{*}{ Concentration $(\mu \mathrm{g} / \mathrm{ml})$} & \multicolumn{2}{|c|}{ Percentage Inhibition (\%)" mean \pm standard deviation (SD) } \\
\hline & Leaf extract & Root extract vitamin C (standard) \\
\hline 500 & $65.81 \pm 1.78$ & $50.12 \pm 8.3453 .12 \pm 13.86$ \\
\hline 250 & $75.14 \pm 3.52$ & $76.38 \pm 2.3256 .17 \pm 13.35$ \\
\hline 125 & $86.63 \pm 2.63$ & $81.03 \pm 3.9157 .68 \pm 12.97$ \\
\hline 62.5 & $92.13 \pm 1.56$ & $89.65 \pm 2.0751 .38 \pm 21.11$ \\
\hline 31.25 & $93.54 \pm 3.21$ & $94.37 \pm 0.5461 .38 \pm 7.80$ \\
\hline 15.625 & $75.12 \pm 12.48$ & $94.23 \pm 2.3047 .93 \pm 4.32$ \\
\hline 7.8125 & $52.04 \pm 22.36$ & $88.16 \pm 5.1844 .69 \pm 8.55$ \\
\hline 3.90625 & $47.58 \pm 20.80$ & $86.04 \pm 2.2431 .16 \pm 4.79$ \\
\hline 1.95325 & $34.43 \pm 12.72$ & $73.18 \pm 4.6517 .61 \pm 7.03$ \\
\hline
\end{tabular}

Values are obtained as mean $\pm \mathrm{SD}$. Each value is the mean of three (03) essays ( $\mathrm{n}=3$ ), $\mathrm{EC}_{50}$ for leaf $=5.93 \mu \mathrm{g} / \mathrm{ml}, \mathrm{EC}_{50}$ for root $=719.45 \mu \mathrm{g} / \mathrm{ml}, \mathrm{EC}{ }_{50}$ for vitamin C (ascorbic acid) standard $=30.27 \mu \mathrm{g} / \mathrm{ml}$.

The scavenging effects of methanol extracts on Uvaria chamae leaves and roots on hydroxyl radical showed a concentration-dependent inhibition with an effective concentration $\left(\mathrm{EC}_{50}\right)$ of $107.89 \mu \mathrm{g} / \mathrm{ml}$ for the leaf extract and $912.01 \mu \mathrm{g} / \mathrm{ml}$ for the root extract compared to that of vitamin C (ascorbic acid) standard with $\mathrm{EC}_{50}$ of $106.66 \mu \mathrm{g} / \mathrm{ml}$. The comparison of leaf extract concentration against the percentage inhibition showed positive correlation that was statistically not significant $(\mathrm{P}>0.05)$ with correlation coefficient $\left(\mathrm{R}^{2}\right)$ of 0.732 while the comparison of the root extract concentration against a percentage inhibition showed a positive correlation that was statistically significant $(\mathrm{P}<0.05)$ with a correlation coefficient $\left(\mathrm{R}^{2}\right)$ of 0.738 .

Table 6: Scavenging effect of methanol extracts (expressed in $\mu \mathrm{g} / \mathrm{ml}$ ) of Uvaria chamae leaves and roots on hydroxyl radical

\begin{tabular}{lll}
\hline Concentration $(\boldsymbol{\mu g} / \mathbf{m l})$ & \multicolumn{2}{l}{ Percentage Inhibition $(\%)^{\mathbf{n}}$ mean \pm standard deviation (S.D.) } \\
\cline { 2 - 3 } & Leaf extract & Root extract vitamin C (standard) \\
\hline 500 & $57.66 \pm 3.48$ & $39.08 \pm 5.5262 .11 \pm 8.20$ \\
250 & $56.08 \pm 3.75$ & $36.62 \pm 6.4260 .16 \pm 10.27$ \\
125 & $53.47 \pm 2.00$ & $36.53 \pm 6.2654 .98 \pm 9.56$ \\
62.5 & $48.14 \pm 3.17$ & $21.61 \pm 9.1648 .56 \pm 5.16$ \\
31.25 & $25.09 \pm 6.79$ & $14.11 \pm 4.2938 .54 \pm 3.69 \pm 3.05$ \\
15.625 & $18.62 \pm 4.74$ & $10.50 \pm 3.0212 .98 \pm 1.57$ \\
7.8125 & $12.34 \pm 3.38$ & \\
\hline
\end{tabular}

Values are obtained as mean $\pm \mathrm{SD}$. Each value is the mean of three (03) essays $(\mathrm{n}=3), \mathrm{EC}_{50}$ for leaf $=107.89 \mu \mathrm{g} / \mathrm{ml}, \mathrm{EC}_{50}$ for root $=912.01 \mu \mathrm{g} / \mathrm{ml}, \mathrm{EC}_{50}$ for vitamin C (ascorbic acid) standard $=106.66 \mu \mathrm{g} / \mathrm{ml}$.

The scavenging effects of $1000 \mu \mathrm{g} / \mathrm{ml}$ methanol extracts of Uvaria chamae leaves and roots on nitric oxide radical showed that at the $30^{\text {th }}, 60^{\text {th }}, 90^{\text {th }}$ and $150^{\text {th }}$ min, there were significant reductions $(\mathrm{p}<$ 0.05 ) on nitric oxide radical showing scavenging effect of the leaf extract but no significant reduction at $120^{\text {th }}$ and $180^{\text {th }}$ min when compared to that of control. There were no significant reductions (p>0.05) on nitric oxide radical by the root extract at $180^{\text {th }}$ min while at another min, the root extract showed marked reductions on nitric oxide radical concentration compared to that of control. The vitamin E standard significantly reduced $<($ p.05) nitric oxide radical at $30^{\text {th }}, 60^{\text {th }}, 90^{\text {th }}$ and $150^{\text {th }}$ min but no reduction at $120^{\text {th }}$ and $180^{\text {th }} \mathrm{min}$. However, the root extract $(1000 \mu \mathrm{g} / \mathrm{ml})$ scavenged nitric oxide radical more than the leaf extract and vitamin E standard at the same concentration when compared to that of control.

\section{DISCUSSION}

Plants produce a significant amount of antioxidants such as phenolics, flavonoids, and polyphenolics to prevent the oxidative stress caused by reactive oxygen species. Many synthetic antioxidants such as butylated hydroxyl anisole (BHA), butylated hydroxyl toluene (BHT), propyl gallate (PG), tert-butyl hydroxyl quinone (TBHQ) protect against oxidative damage but they have some adverse side effects, and this has prompted mass campaign to search for natural foods, herbs, and spices that are rich in antioxidants. Many natural antioxidants have been isolated from roots, leaves, stems, and barks of different plants [18-20]. The antioxidant and polyphenolic contents of Uvaria chamae seed [21], root bark [22] and root [23] have been determined whereas in this study, the antioxidant capacity and free radial scavenging potentials of Uvaria chamae leaves and roots were measured.

Higher concentration of Vitamin A and C with the values of $4871 \pm 79.21 \mathrm{I}$. $\mathrm{U}$ and $1.72 \pm 0.02 \%$ respectively in Uvaria chamae leaf extract could suggest its anti-radical scavenging activities more than the root extract with the values of $673.28 \pm 0.00 \mathrm{I}$. $\mathrm{U}$ and $1.66 \pm 0.01 \%$ respectively. Several studies have reported that the scavenging property could be used in the management of free radical oriented diseases. However, the results suggest that Uvaria chamae leaf could be recommended as an antioxidant supplement and could be used to manage pro-oxidant-related ailments. Moreover, both plant parts contain an equal amount of vitamin E $(8.83 \pm 0.04 \mathrm{mg} / 100 \mathrm{~g})$. Hence, the root extract could also serve in scavenging free radical since vitamin $\mathrm{C}$ works synergistically with vitamin $\mathrm{E}$.

The result of the antioxidant potentials of the leaf extract showed rapid scavenging activity on the superoxide radical and hydroxyl radical while the root extract rapidly scavenged only DPPH and nitric oxide radicals. This could suggest that the leaf and root extracts contains some secondary antioxidant metabolites that could make both extracts medicinally relevant. It is reported by most 
studies that the efficacies of antioxidants are often associated with their ability to scavenge stable, highly reactive, free radicals.

The concentration-dependent percentage inhibitions observed for both the leaf and root extracts on DPPH radical showed EC ${ }_{50}$ of 31.19 $\mu \mathrm{g} / \mathrm{ml}$ and $14.00 \mu \mathrm{g} / \mathrm{ml}$ respectively compared to the ascorbic acid standard with the $\mathrm{EC}_{50}(25.29 \mu \mathrm{g} / \mathrm{ml})$. Both the leaf and root extracts showed a statistically strong significan $\leqslant 0 .(5)$ positive correlation, $\mathrm{R}^{2}$ of 0.839 and 0.778 respectively suggesting moderate scavenging activities of both extracts against the DPPH radical.

The concentration-dependent percentage inhibitions observed for both the leaf and root extracts on superoxide radical showed EC 50 of $5.93 \mu \mathrm{g} / \mathrm{ml}$ and $719.45 \mu \mathrm{g} / \mathrm{ml}$ respectively compared to the ascorbic acid standard with the $\mathrm{EC}_{50}$ of $30.27 \mu \mathrm{g} / \mathrm{ml}$. Both the leaf and root extracts also showed no statistically significant (40.05) positive correlation and a statistically significant $(\mathrm{p} \leq 0.05)$ negative correlation respectively with correlation coefficient, $\mathrm{R}^{2}$ of 0.139 and-0.855 respectively suggesting a moderate scavenging activity of the leaf extract more than the root extract against the superoxide radical.

The concentration-dependent percentage inhibitions observed for both the leaf and root extracts on hydroxyl radical showed an $\mathrm{EC}_{50}$ of $107.89 \mu \mathrm{g} / \mathrm{ml}$ and $912.01 \mu \mathrm{g} / \mathrm{ml}$ respectively compared to the vitamin E standard with $\mathrm{EC}_{50}$ of $106.66 \mu \mathrm{g} / \mathrm{ml}$. Both the leaf and root extracts showed a positive correlation that is statistically not significant $(\mathrm{p} \geq 0.05)$ with a correlation coefficient $\left(\mathrm{R}^{2}\right)$ of 0.732 and 0.738 suggesting moderate scavenging activities of the extracts against hydroxyl radical.

The scavenging activity of the extracts at the concentrations of $1000 \mu \mathrm{g} / \mathrm{ml}, 500 \mu \mathrm{g} / \mathrm{ml}$ and $250 \mu \mathrm{g} / \mathrm{ml}$ for nitric oxide radical could suggest that root extract is more effective than the leaf extract and the vitamin E standard at the concentrations of $1000 \mu \mathrm{g} / \mathrm{ml}$ and $250 \mu \mathrm{g} / \mathrm{ml}$ while at the concentration of $500 \mu \mathrm{g} / \mathrm{ml}$, the leaf extract was more effective than the root extract and the vitamin E standard. All these results could suggest that both extracts could be useful in the management of free radical-related diseases.

In conclusion, the leaf extract of Uvariae charmae is rich in useful phytochemicals and possesses moderate antioxidant activity more than the root extract.

\section{AUTHORS CONTRIBUTIONS}

Nwokolo Lorreta Nwakaego, Onyekwelu Kenechukwu Chibuike and Ene Martin Chukwugekwu conceived and designed the experiments, performed laboratory analysis/experiments, data analysis and participated in the writing and editing of the manuscript.

Ezeh Richard Chukwunonye, Adilieje Chioma Marylyn and Ezechukwu Ifunanya Ngozi participated in the analysis of the data and preparation of the initial draft of the manuscript and helped in the laboratory experiments.

\section{CONFLICTS OF INTERESTS}

We have no conflict of interest to declare.

\section{REFERENCES}

1. Boxin OU, Dejian H, Maureen AF, Elizabeth KD. Analysis of antioxidant activities of common vegetables employing oxygen radical absorbance capacity (ORAC) and ferric reducing antioxidant power (FRAP) assays: a comparative study. J Agric Food Chem 2002;5:223-8.

2. Inoue M, Sato EF, Nishikawa M, Park AM, Kira Y, Imada I, et al. Mitochondrial generation of reactive oxygen species and its role in aerobic life. Curr Med Chem 2003;10:2495-505.
3. Capdevila J, Parkhill L, Chacos N, Okita R, Masters BS, Estabrook RW. The oxidative metabolism of arachidonic acid by purified cytochromes P-450. Biochem Biophys Res Commun 1981;101:1357-63.

4. Valko M, Izakovic M, Mazur M, Rhodes CJ, Telser J. Role of oxygen radicals in DNA damage and cancer incidence. Mol Cell Biochem 2004;266:37-56.

5. Lindahl T. Instability and decay of the primary structure of DNA. Nature 1993;362:709-15.

6. Wagner BA, Buettner GR, Burns CP. Free radical-mediated lipid peroxidation in cells: oxidizability is a function of cell lipid bisallylic hydrogen content. Biochemistry 1994;33:4449-53.

7. Ridnour LA, Thomas DD, Mancardi D, Espey MG, Miranda KM, Paolocci $\mathrm{N}$, et al. The chemistry of nitrosative stress induced by nitric oxide and reactive nitrogen oxide species. Putting perspective on stressful biological situations. Biol Chem 2004;385:1-10.

8. Mahanta M, Mukherjee AK. Neutralisation of lethality, myotoxicity and toxic enzymes of naja kaouthia venom by mimosa pudica root extracts. J Ethnopharmacol 2001;75:55-60.

9. Ioan C. Methodology for analysis of vegetable drugs. Faculty of Pharma, Eucharest Romania; 1984.

10. Velioglu YS, Mazza G, Gao L, Oomah BD. Antioxidant activity and total phenolics in selected fruits, vegetables and grain products. J Agric Food Chem 1998;46:4113-7.

11. Makkar APS, Blumel M, Borowy NK, Becker K. Gravimetric determination of tannins and their correlations with chemical and protein precipitation methods. J Sci Food Agric 1993;61:161-5.

12. Kumaran A, Karunakaran RJ. Antioxidant and free radical scavenging activity of an aqueous extract of Coleus aromaticus. Food Chem 2006;97:109-14.

13. Pearson DA. Chemical analysis of food. $7^{\text {th }}$ Edn. Churchill Livinstone Edinburgh, London; 1976.

14. Gyamfi MA, Yonamine M, Aniya Y. Free-radical scavenging action of medicinal herbs from ghana: Thonningia sanguine on experimentally-induced liver injuries. Gen Pharmacol 1999; 32:661-7.

15. Elizabeth K, Rao MNA. Oxygen radical scavenging activity of curcumin. Int J Pharm 1990;58:237-40.

16. Fontana M, Mosca L, Rosei MA. Interaction of enkephalines with oxyradicals. Biochem Pharmacol 2001;61:1253-7.

17. Marcocci L, Maguire JJ, Droy Lefaix MT, Packer L. The nitric oxide scavenging properties of Ginkgo biloba extract. Biochem Biophys Res Commun 1994;201:748-55.

18. Yadav SB, Tripathi V, Singh RK, Pandey HP. Flavonoid glycosides from Cuscuta reflexa stems and their antioxidant activity. Indian Drugs 2001;38:95-6.

19. Sam SKG, Senthil KB, Ramachandran S, Saravanan M, Sridhar SK. Antioxidant and wound healing properties of Glycyrrhiza glabra root extract. Indian Drugs 2001;38:355-7.

20. Morteza Semnani K, Saeedi M, Shahnavaz B. Comparison of antioxidant activity of extract from roots of liquorice (Glycyrrhiza glabra L.) to commercial antioxidants in $2 \%$ hydroquinone cream. J Cosmet Sci 2003;54:551-8.

21. Ita BN. Antioxidant activity of Cnestis ferruginea and Uvaria chamae seed extracts. Br J Pharm Res 2017;16:1-8.

22. Chinaka ON, Julius 00, Motunrayo GA. In vitro antioxidant potentials of some herbal plants from Southern Nigeria. J Med Sci 2013;13:56-61.

23. Kone M, Toure A, Ouattara K, Coulibaly A. Phytochemical composition, antioxidant and antibacterial activities of root of uvaria chamae P. Beauv. (Annonaceae) used in the treatment of dysentery in North of Côte d'Ivoire. Int J Pharmacogn Phytochem Res 2015;7:1047-53. 